\title{
PENGEMBANGAN MULTIMEDIA PEMBELAJARAN IPS BERBASIS HERITAGE UNTUK MENINGKATKAN HASIL BELAJAR PADA SISWA SMP NEGERI KOTA MADIUN
}

\author{
Khoirul Huda \\ Program Studi Pendidikan Sejarah, FPIPS, IKIP PGRI MADIUN \\ Email :aairul_ni@yahoo.com
}

\begin{abstract}
Abstrak
Perkembangan pemanfaatan beragam aplikasi modern saat ini cukup bervariasi dan memberi peluang pendidik guna merancang komponen pengajaran yang menarik terutama media pembelajaran.Tetapi perihal pemanfaatannya jarang terlihat di SMP Kota Madiun.Berdasarkan pengamatan diperoleh informasi bahwa kurang adanya pengembangan media pemanfaatan komponen multimedia dan aspek materi belum memanfaatkan potensi lingkungan sekitaruntuk sumber belajar.Tujuan penelitian untuk mengembangkan multimedia heritage sampai terbentuk prototype media yang telah diuji.Jenis penelitian adalah R\&D. Hasil penelitian bahwa pada skala diperluas di SMP N 6 Madiun menunjukkan perbedaan signifikan sebelum dan sesudah diterapkan multimedia heritage.Terbukti nilai pre-test 64,64 dan post-test 93,21 dengan signifikansi 0,05 kemudian diuji statistik model Paired Samples $\mathrm{T}$ Test.Sehubungan aturan hipotesis statistik nilai perhitungan tersebut adalah $<0,05$, makaH $_{U}$ ditolak. Kesimpulan hipotesisnya $\mathrm{H}_{1}$ diterimasehingga ada peningkatan signifikan nilai siswa sebelum dan sesudah diberi multimedia heritage. Dapat disimpulkan media yang dikembangkan efektif untuk meningkatkan hasil belajar siswa.
\end{abstract}

Kata Kunci :Multimedia, Heritage, IPS, Hasil belajar siswa

\section{Developing M ultimedia Learning of Social Science B ased on Region's H eritage to Enhance Learning Achievement of SMP Students in Madiun}

\begin{abstract}
The development on the use of various modern application today increases and gives a chance for teachers to design interesting teaching components namely learning media. Unfortunately, the use of the media is rarely applied in SMP of Madiun city. Based on the observation, it is gained that there is still lack of the multimedia development using potential source in the surrounding as the content. This study aims to develop multimedia based on the region's heritage in the form of a prototype that has been tested. The study used Research and Development $(R \& D)$ design. The results show that there is a significant different between pre-application and post-application of multimedia based on region's heritage in SMP N 6 Madiun. It is seen from the pre-test score at 64.64 and post-test score at 93,21 in the level of significance 0,5 that is tested by using paired samples T-test. It is, therefore, <0,05, HO is rejected. In conclusion, $\mathrm{HI}$ is accepted. It means that there is a significant increase of students score before implementing the multimedia and after implementing the multimedia. Thus, the multimedia that is developed, effectively enhance the students' learning achievement.
\end{abstract}

Keywords: Multimedia, hegion's heritage, social science, students' learning achievement

\section{Pendahuluan}

Mencermati kondisi pendidikan sekarang cenderung mengarah ke perubahan pada paradigma yang baru. Adanya transisi tersebut ditandai dengan transformasi pandangan dari sifat behavioristik menuju konstruktivisme. Konsep perubahan itu juga dimaknai pula bahwa telah terjadi untuk mentransisi filosofi dari prahistoris ke historis 
yang diperkenalkan oleh Jan Patocka (dalam Haryono, 2013: 11). Prahistoris dimaknai sebagai keadaan pendidik yang masih terjebak terhadap sifat pembelajaran konvensional. Model dan strategi masih menekankan pengajaran tradisional seperti ceramah bervariasi, buku teks sebagai sumber ajar dan sejenisnya. Sebaliknya, makna historis diasumsikan untuk model pembelajaran yang mampu menerapkan kombinasi pengajaran dengan inovasi dan kreativitas seorang pendidik dalam mendayagunakan dan mengembangkan komponen pembelajaran. Sinkronisasi ide yang dituangkan dalam inovasi pembelajaran difungsikan untuk mengubah pembelajaran yang menyenangkan sekaligus bermakna yang sasaranya dapat menguatkan kualitas sumber daya terdidik dengan kualitas yang seimbang.

Esensi kualitas tersebut menekankan upaya pengubahan perilaku sebagai hasil dari proses belajar. Keterkaitan esensi tersebut sebagai wujud substansi pendidikan memungkinkan membentuk kepribadian peserta didik yang unggul, berkarakter dan mampu mengembangkan wawasan keilmuannya.Perlunya rancangandesain pendidikan dalam mengupayakan pembentukan kepribadian tersebut harus mendapatkan porsi mendalam dengan menekankan proses pembelajaran yang kompatible. Minimal dapat mencapai konstruksi kepribadian yang berkarakter humanis. Maka pendidik mempunyai peran penting dalam proses transformasi pembelajaran. Transformasi tersebut dapat melalui penguasaan strategi, materi, atau media yang inovatif. Pendidikmempunyai tanggung jawab vital terhadap transformasi pengetahuan. Mengingat di masa saat iniformulasi pengembangan inovasi pembelajaran berupa model, strategi, atau media menjadi tuntutan dan kebutuhan utama bagi seorang pendidik. Logika berfikir sederhananya adalah apabila guru mampu mengembangkan inovasi pembelajaran tentu peserta didik dapat memahami dengan mudah materi yang diajarkan, begitu sebaliknya. Terkait dengan ini, bidang ilmu IPS sering dinodai dengan paradigma pembelajaran yang kurang menekankan variasinya. Hal ini disebabkan penyelenggaraan pembelajaran IPSterutama Sejarah sering ditemukan prosesnya dengan pendekatan konvensional. Kondisi tersebut berdampak psikologis pada anggapan khalayak umum dan peserta didik itu sendiribahwa pembelajarannyatelah tersigma kurang memiliki makna. Hal ini akan berakibat pada proses pembelajaran menjadi membosankan dan tidak menarik (Nur Ahyani, 2013: 13). Keadaan yang demikian itu sebagai akibat membudayanya kualitas pembelajaran yang bersifat oriented prahistoris. Kondisi ini seperti yang sering ditemukan dalam proses pembelajaran IPS Sejarah di SMP N 06 Kota Madiun.

Berdasarkan pengamatan dan sejumlah informasi bahwa pembelajaran IPS di SMP Negeri 6 Madiun belum menunjukkan arah pengembangan pengajaran. Keadaan ini ditunjukkan dengan temuan observasi dan wawancara yaitu Pertamametode yang digunakan selama pembelajaran masih terorientasi ceramah bervariasi, Keduabelum adanya pengembangan media dengan memanfaatkan komponen multimedia sebagai perantara untuk menyampaikan materi ke peserta didik. Padahal ruang kelas telah dilengkapi LCD, proyektor dan seperangkat audio yang bisa sebenarnya bisa dimanfaatkan, Ketiga dalam aspek materi belum memanfaatkan sumber belajar lingkungan sekitar mempunyai potensi untuk dijadikan sumber belajar. Terutama potensi kearifan lokal yaitu beragam peninggalan Heritage. Salah satunya adalah Kota dan Kabupaten Madiun.Apabila dieksplorasi ternyata masih terdapat banyak aktifitas lain pada masa itu yang memainkan peran penting dalam peristiwa sejarah Indonesia, dibuktikan dari banyaknya manusia di wilayah Madiun khususnya mengenai bangunan bersejarah (Team dalam Agastya, 2012: 89).

Keberadaan heritage Madiun berpotensi dimanfaatkan menjadi pengembangan bahan materi dengan kemasan variasi media pembelajaranyang menarik. Orientasisintesa tersebut lebih pada penguatan akulturasi nilai 
budaya yang setelah dikenalkan diharapkan dapat membentuk identitas seseorang. Identitas merupakan ungkapan nilai budaya bangsa yang bersifat khas dan membedakan dengan bangsa lain (Dian Din Satuti Mulia, 2014 : 21). Oleh karena itu, perlu dilakukan sebuah formulasi pengembangan media berbasis orientedcontextual.Salah satu formulasi pengembangan media pembelajaran yang ditawarkan adalah multimedia heritage. Jenis multimedia cukup beragam. Namun dalam konteks ini media yang dikembangkan merupakan hasil visualisasi peninggalan heritage yang bersifat tangible di Madiun yang dikemas melalui video. Pemilihan multimedia berbasis video menjadi pertimbangan penulis. Merujuk hasil riset yang pernah dilakukan bahwa dari penelitian Suppes dan Morning Star tahun 1972 mengenai efektifitas pemanfaatan CAI untuk proses pembelajaran dengan menggunakan sampel besar dari kelas 1 sampai 6 di daerah Missisippi melalui latihan berhitung. Kelompok eksperimental menggunakan CAI mempelajari bahasa asing dengan kelompok siswa yang belajar melalui bicara dan tulisan dengan treatmentsama yaitu lima jam dalam seminggu. Hasilnya membuktikan $73 \%$ kelompok eksperimen dapat menyelesaikan penuh pelajaran selama setahun, sedangkan kelompok non-eksperimen hanya memperoleh persentase $32 \%$. Dapat disimpulkan pemanfaatan CAI untuk membuat dan menggabungkan teks, grafik, audio, gambar bergerak (video dan animasi) berhasil (Deni Darmawan, 2012: 52-53).

Selain itu, penelitian dari Mohd. Salleh Abu dan Zaid Zainal Abiding Tahun 2013 dalam International Journal of Evaluation and Research in Education dengan judul "ImprovingThe Levels of Geometric Thinking of Secondary School Students Using
Geometry Learning Video Based on Van Hiele Theory" menunjukkan hal yang sama. Riset ini merupakan video pendidikan yang disebut geometri pembelajaran video (VPG) guna meningkatkan tingkat pemikiran geometris melalui teori van Hiele. VPG dirancang sebagai alat bantu alternatif untuk mengatasi keterbatasan ICT di parepare Indonesia untuk siswa SMP. Hasilnya bahwaefektivitas VPG diuji 180 siswa dikategorikan sebagai 90 siswa dari level 0 (L0), 60 siswa dari level 1 (L1), dan 30 siswa dari level 2 (L2). Komparatif analisis hasil tes disesuaikan model Van Hiele geometri (VHGT) pra dan pasca penggunaan VPG yang menunjukkan ada perbedaan signifikan antara nilai rata-rata. Hal itumenandakan peningkatan signifikan dalam tingkat pemikiran geometrik terjadi sebagian besar siswa.Oleh sebab itu, berdasarkan bukti penelitian sebelumnya, maka multimedia heritage dijadikan inovasi untuk dikembangkan menjadi sebuah media pembelajaran.Hal ini beralasan bahwa video telah terbukti dapat membantu capaian kompetensi pembelajaran dari aspek pengetahuan, makna belajar, dan membangun pemahaman dan kesadaran budaya terutama siswa tingkat SMP.

\section{Metode Penelitian}

Desain penelitian merupakanResearch and Developmentdengan langkah Borg and Gall (2007).Sugiyono (2013: 297) mengatakanR\&D adalah salah satu model penelitian yang digunakan untuk menghasilkan produk tertentu dan menguji keefektifan produk yang dihasilkan.Di dalam penelitian ini sintaks pengembangan telah termodifikasi hingga langkah uji yang diperluas seperti ditunjukkan Gambar 1: 

Avaliable online at http://e-journal.ikippgrimadiun.ac.id/index.php/gulawentah

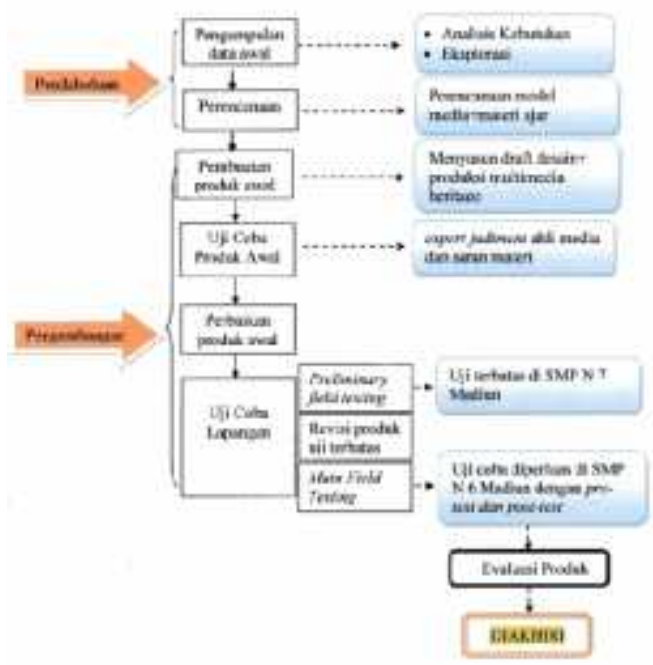

Gambar 1. Siklus Penelitian adaptasi dan modifikasi R\&D Borg and Gall

\section{Prosedur Penelitian}

Dalam Pengembangan ini, penjabaran prosedur penelitian sesuai siklus dari Borg and Gall termodifikasi adalah sebagai berikut:

a) Studi Pendahuluan

Needs Assessment

Analisis kebutuhan dilakukan dengan pengumpulan informasi awal.Eksplorasi informasi dengan studi pustaka guna menghimpun landasan teoritik sebagai bahan untuk pentingnya pengembangan inovasi media pembelajaran berbasis multimedia.Selanjutnya, riset lapangan yang akan didapatkan tentang informasipenggunaan media yang pernah dilakukan oleh pendidik mengenai pemanfaatan sumber belajar lingkungan sekitar dan merencanakan materi sebagai bahan pengembangan.

\section{Tahap Perencanaan}

Tahap ini masih berupa sebuah draft rancangan awal video heritage terutama konten materinya. Perencanaan dapat dikatakan bagaimana langkah untuk membuat multimedia berbasis heritage dan kelengkapan apa saja yang harus disiapkan untuk memproduksi multiemdia tersebut. Pada tahap pembuatan rancangan draft awal ini meliputi beberapa langkah yaitu menyiapkan bahan materi, menyusun isi video hingga produksinya. gambar 2 menunjukkan rancangan dalam menyusun multimedia heritage

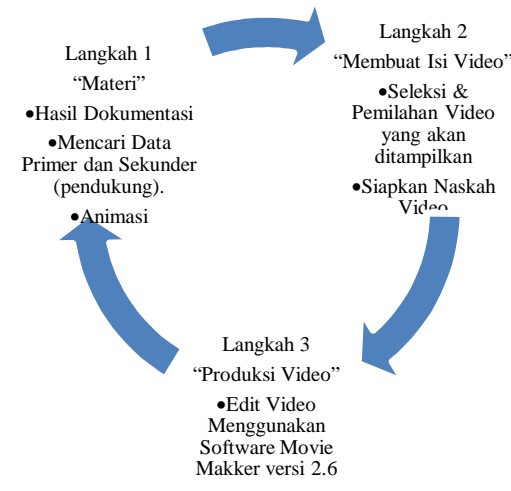

Gambar 2. Skema Menyusun Multimedia Heritage 

Avaliable online at http://e-journal.ikippgrimadiun.ac.id/index.php/gulawentah

b) Tahap Pengembangan Model

1) Desain produk

Tahap ini dengan membuat video heritage. Langkah awalnya dengan merekam benda heritage di Madiun dan kemudian disusun menggunakan software editor video yaitu Movie Maker versi 2.6.

2) Validasi Desain Produk

Validasi desain ini untuk mengetahui sejauhmana media video Heritagetelah siap ujicoba dilapangan.Rencana validator ahlimedia adalah Dr. Nunuk Suryani, M.Pd, (Ketua Prodi Teknologi Pendidikan PPs UNS), saran materi adalah Hery Priswanto, S.S. dan Dra. T.M. Rita Istari (Peneliti Balai Arkeologi Yogyakarta) serta Arif Ardianto, S.S, (Pamong Budaya Kemendikbud Rayon Jawa Wilayah Kabupaten Madiun).

3) Revisi Desain

Revisi desain produk dilakukan sesuai masukan dan saran ahli media pembelajaran sertasaran ahli materi.

4) Ujicoba Produk

Uji Coba Skala Terbatas

Tahapini menggunakan metode eksperimen model Single One-Shot Case Study seperti ditunjukkan pada gambar gambar 3.

\section{0}

\section{Gambar 3.Design single One-Shot Case Study}

(Sumber: Sugiyono, 2013: 110)

Keterangan

$\mathrm{X}$ : Treatment yang diberikan (variable independen)

$\mathrm{O}$ : Observasi (Variabel dependen)

Untuk teknik Analisis Databerupa penskoran dengan pedomankonversi pada skala lima seperti tabel 3 berikut ini:

Tabel 1.Patokan dengan perhitungan persentase untuk skala lima

\begin{tabular}{cccc}
\hline \multirow{2}{*}{$\begin{array}{c}\text { Interval persentase } \\
\text { tingkat penilaian }\end{array}$} & \multicolumn{2}{c}{ Nilai ubah skala } & \multirow{2}{*}{ Keterangan } \\
\cline { 2 - 3 } & $1-5$ & E-A & \\
\hline $85 \%-100 \%$ & 5 & $\mathrm{~A}$ & Baik sekali \\
\hline $75 \%-84 \%$ & 4 & $\mathrm{~B}$ & Baik \\
\hline $60 \%-74 \%$ & 3 & $\mathrm{C}$ & Cukup \\
\hline $40 \%-59 \%$ & 2 & $\mathrm{D}$ & Kurang \\
\hline $0 \%-39 \%$ & 1 & $\mathrm{E}$ & Sangat kurang \\
\hline
\end{tabular}

(Sumber: Modifikasi dari Erna Febri Aris, 2011: 60)

Uji Coba SkalaDiperluas

Metode yang digunakan adalah preexperimental design (non-designs) tipe one-group pretest-posttestdesign seperti yang ditunjukkan pada gambar 4:

$$
\mathrm{O}_{1} \quad \mathbf{X} \quad \mathrm{O}_{2}
$$

Gambar 4. Desain One-Group pretest-postest (Sugiyono, 2013: 110)

Keterangan:

$\mathrm{O}_{1} \quad$ : Nilai Pre-test (keadaan sebelum diberi perlakuan)

$\mathrm{O}_{2}:$ Nilai Post-test (setelah diberi perlakuan)

$\mathrm{X} \quad$ : Treatment (menggunakan media multimedia Heritage). 
Teknik uji yang dipakai adalah statistik parametric dengan model Paired Sample t Test dan pengolahan data menggunakan program SPSS versi 16. Hipotesis yang diajukan adalah

$$
\begin{aligned}
& H_{0} \text { : Tidak ada perbedaan nilai siswa } \\
& H_{1} \text { : Ada perbedaan nilai siswa sebelum } \\
& \text { dan sesudah diberi perlakuan } \\
& \text { Taraf signifikansi 0,05 dengan }
\end{aligned}
$$

\section{Hasil Penelitian dan Pembahasan}

\section{Hasil Pengembangan Multimedia Herittage}

Pengembangan media dengan multimedia berbasis heritage ini menggunakan Model IDI (institute development instructional). Model IDI diaplikasikan dengan prosedur dari siklus Borg and Gall yang termodifikasi. Pengembangan media pembelajaran ini mempunyai tujuan untuk memberikan pemahaman dan pengetahuan kepada siswa kelas VII SMP Negeri 6 Madiun.Secara teoritik, siswa kelas VII SMP masih menggunakan alur pikirbasic logika dengan memiliki kemampuan daya serap otak yang mampu menalar secara logis berbagai informasi yang diperoleh dari orang lain terutama guru.Sasaran materi adalah mendeskripsikan masyarakat pada masa Hindu-Budha dan Islam serta peninggalanpeninggalannya di berbagai daerah. Tema ini berbasis pada narasi bukti sejarah daerah masa lampau dengan proses produksi melalui aplikasi movie maker versi 2.6 untuk menghasilkan media video menarik sehingga mampu memberikan informasi dan termemori pada nalar siswa. Penerapan penelitian ini melaluidua tahap yaitu Pertama, validasi produk ahli media, Kedua penerapan ujicoba dengan skala terbatas dan skala luas.Berdasarkan uraian tersebut, maka proses dan hasil pengembangan multimedia heritage sebagai berikut:

\section{Hasil Uji Validasi Ahli}

Hasil perhitungan diperoleh ratarata skor 4, 22. Bilamana mengacu skor yang diperoleh, maka angka tersebut menunjukkan kategori sangat baik. Terbuktihasil sebaran data frekuensi yang ditinjau dari berbagai aspek sebagai berikut, Pertamaaspek media dengan kriteria sangat baik $(40,2 \%)$, baik (44.5\%), cukup (11,9\%), dan kurang (3\%), Kedua, aspek materi dengan kriteria sangat baik $(38,3 \%)$, baik $(41,6 \%)$, dan $20,0 \%)$, serta Ketiga, aspek pembelajaran dengan kriteria sangat baik $(33,3 \%)$, baik $(48,8 \%)$ dan cukup $(17,7 \%)$. Dengan demikian, hasil penilaian ahli media terhadap draft media yang dikembangkan layak sehingga dapat digunakan untuk media pembelajaran IPS Sejarah kelas VII.

\section{Hasil Implementasi Ujicoba \\ Ujicoba skala Terbatas}

Tahap ini dimaksudkan untuk mendapatkan penilaiandarft produk setelah dilakukan uji oleh pakar media dan materi. Tujuannya adalah untuk memperoleh masukan, saran berkaitan dengan kekurangan produk yang dikembangkan. Saran dan masukan yang diterima sebagai berikut Pertama, seyogyanya peninggalanpeninggalan di daerah Madiun dalam isi video ditambah lebih banyak, Kedua ada penjelasan singkat mengenai gambar peninggalan yang lebih memungkinkan agar memiliki makna yang lebih kuat, Ketiga sebaiknya isi video lebih diperjelas dan jangan terlalu cepat, dan Keempat keterangan tulisan dalam video jangan terlalu cepat karena tidak bisa mencerna arti atau makna dalam isi kalimat tersebut. Dalam konteks ini, diperoleh pula kesimpulan dan gambaran bilamana media pengembangan ini disimulasikan kepada siswa SMP. Uji terbatas diterapkan di satu sekolah, yaitu SMP Negeri 7 Madiun dengan jumlah subyek sebanyak 15 siswa. Hasil dari uji coba terbatas dan berdasarkan angket yang 
disebarkan menyebutkan bahwa media video tersebut layak, menarik dan dapat memberikan pengetahuan baru kepada siswa.Terbukti dari skor nilai rata-rata yang diperoleh adalah 4,22. Berdasarkan pengkonversian angka tersebut, maka menunjukkan keterangan sangat baik.Bukti lain sebagai penguatan hasil konservasi adalah akumulasi sebaran data frekuensi dari berbagai aspek penilaian.

Pertama adalah aspek media dengan kriteria sangat baik $(40,2 \%)$, kriteria baik $(44.5 \%)$, kriteria cukup $(11,9 \%)$, dan kriteria kurang (3\%),Kedua aspek materi dengan kriteria sangat baik $(38,3 \%)$, kriteria baik $(41,6 \%)$, dan kriteria kurang $(20,0 \%)$, serta Ketiga aspek pembelajaran dengan kriteria sangat baik $(33,3 \%)$, kriteria baik $(48,8 \%)$ dan kriteria cukup $(17,7 \%)$. Apabila ketiga aspek penilaian diformulasikan melalui persentase maka hasil skor rata-rata aspek media adalah sebanyak 4,21\%, aspek materi sebanyak $4,18 \%$, dan aspek pembelajaran menunjukkan angka $4,15 \%$. Berpijak dari hasil perolehan persentase tersebut, maka dapat membuktikan bahwa media yang dikembangkan memang layak untuk dipergunakan dalam pembelajaran IPS.

\section{Ujicoba Skala Luas}

Pada tahap uji skala luas hakikatnya bertujuan untuk melihat keberhasilan draft desain video yang dirancang untuk pembelajaran IPS siswa SMP kelas VII. Uji coba skala luas, dilakukan SMP Negeri 6 Madiun.Untuk sasaran pengukuran adalah adanya peningkatan keberhasilan siswa dalam hal kemampuan hasil belajar. Hasil dari uji coba yang telah dilakukan rata-rata menyebutkan bahwa kemampuan siswa setelah mendapatkan pelakuan dengan multimedia heritage mengalami peningkatan secara signifikan.Terbukti dari perolehan nilai pre-test dan post-test yang mengalami peningkatan. Perolehan hasil pada pengujian di SMP Negeri 6 Madiun denagan jumlah siswa 28 orang menunjukkan nilai pre-test 64,64 dan nilai post-test 93,21 dengan nilai signifikansinya 0,05 . Dari perolehan data sementara tersebut kemudian dilakukan perhitungan uji statistik dengan model Paired Samples $T$ Test (Non-Independent). Sehubungan dengan jenis model statistik tersebut adalah parametrik maka ada persyaratan yang harus ditempuh yaitudengan dilakukan uji normalitas untuk mengetahui sebaran data itu berdistribusi normal. Uji normalitas menggunakan model One-Sample Kolmogorov-Smirnov Test dengan program SPSS versi 16 dan hasil perhitungannya sebagai berikut:

NPar tests

One-Sample Kolmogorov-Smirnov Test

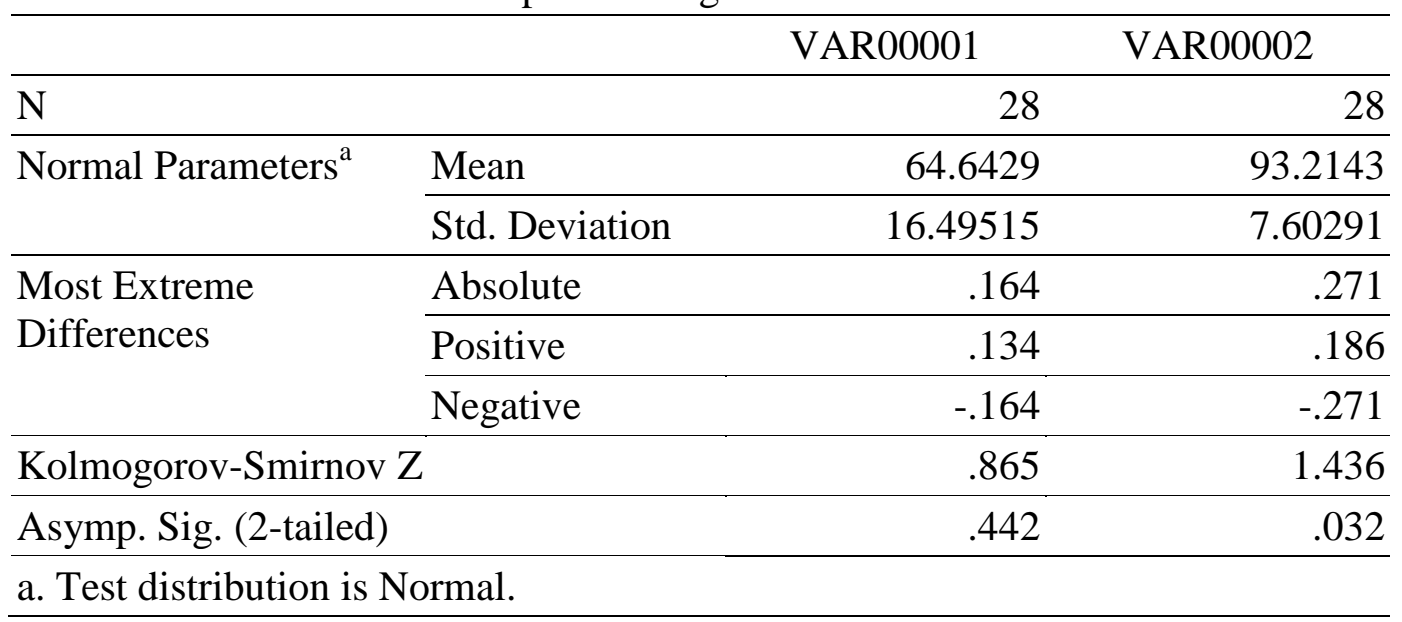



Avaliable online at http://e-journal.ikippgrimadiun.ac.id/index.php/gulawentah

Data dianggap berdistribusi normal apabila perhitungan statistik menghasilkan signifikansi $>0,05$. Berdasarkan perhitungan, nilai signifikansi pre-test adalah 0.442 dan post-test adalah 0.032.Kesimpulan menyatakan data berdistribusi normal. Tahap selanjutnya dilakukan uji t. Uji t dimaksudkanagar mengetahui seberapa besar t-Test pengaruh apabila setiap sampel diberikan perlakuanmultimedia heritage yang telah dikembangkan. Jenis statistik yang digunakan adalah Paired Sample T Test dengan alasan yang dibandingkan hanya satu subyek saja dengan dua perlakuan yang menghasilkan luaran hitung sebagai berikut

Paired Samples Statistics

\begin{tabular}{|c|c|c|c|c|c|}
\hline & & Mean & $\mathrm{N}$ & Std. Deviation & Std. Error Mean \\
\hline \multirow[t]{2}{*}{ Pair 1} & Pretest & 64.6429 & 28 & 16.49515 & 3.11729 \\
\hline & posttest & 93.2143 & 28 & 7.60291 & 1.43681 \\
\hline \multicolumn{6}{|c|}{ Paired Samples Correlations } \\
\hline \multicolumn{4}{|c|}{$\mathrm{N}$} & Correlation & Sig. \\
\hline Pair 1 & pretest $d$ & & 28 & & .593 \\
\hline
\end{tabular}

Paired Samples Test

\begin{tabular}{|c|c|c|c|c|c|c|}
\hline & & \multicolumn{5}{|c|}{ Paired Differences } \\
\hline & & \multirow{2}{*}{ Mean } & \multirow{2}{*}{$\begin{array}{c}\text { Std. } \\
\text { Deviation }\end{array}$} & \multirow{2}{*}{$\begin{array}{l}\text { Std. Error } \\
\text { Mean }\end{array}$} & \multicolumn{2}{|c|}{$\begin{array}{l}95 \% \text { Confidence Interval of } \\
\text { the Difference }\end{array}$} \\
\hline & & & & & Lower & Upper \\
\hline \multirow[t]{3}{*}{ Pair 1} & VR1 - VR2 & -28.57143 & 13.46168 & 2.54402 & -33.79132 & -23.35153 \\
\hline & & $\mathrm{T}$ & Df & Sig. (2-tailed) & & \\
\hline & & -11.231 & 27 & .000 & & \\
\hline
\end{tabular}

Berdasarkan hasil tersebut, nilai signifikansinya 0.000.Apabila mengacu aturan hipotesis statistik (lihat teknik uji analisis data skala diperluas bagian metode penelitian), nilai perhitungan tersebut adalah $<0,05$, dan itu artinya $H_{0}$ ditolak. Kesimpulan hipotesis tersebut adalah bahwa $H_{1}$ yang diterimasehingga ada peningkatan positif dan signifikan antara nilai siswa sebelum dan sesudah diberi multimedia heritage (media yang dikembangkan). Menyikapi perolehan hasil pengembangan media yang dilakukan, maka secara keseluruhan dapat disimpulkan bahwa desain draft media pembelajaran multimedia berbasis Heritage, dapat dikatakan berhasil untuk meningkatkan hasil belajar IPS
SMP kelas VII. Argumentasi tersebut cukup beralasan sebab, menurut perhitungan akhir skor di sekolah yang dipakai uji coba yaitu SMP Negeri 6 Madiun menunjukkan perubahan nilai yang signifikan. Keberhasilan dalam berbagai tahap ujicoba membuktikan bahwa multimedia berbasis heritage merupakan salah satu variasi bentuk media pembelajaran yang penting. Bilamana dikaji secara empirik, multimedia heritage menawarkan sebuah sajian alat bantu pembelajaran dengan konsep pendekatan pengalaman belajar langsung. Pengalaman langsung diperoleh melalui penyajian gambar nyata yang dibuat dalam bentuk video sehingga secara langsung dapat 
mempengaruhi dan memberikan pengetahuan baru siswa.

Di samping itu, konteks peranan media secara teoritik telah disinggung oleh Edgar Dale melalui teori "cone of experience". Teori tersebut telah menjadi pedoman pendidik untuk menentukan media atau proses belajar yang seperti apa agar menuntun siswa dalam mencapai sasaran keberhasilan pengetahuan. Edgar Dale (dalam Wina Sanjaya, 2008: 199200) menjelaskan bahwa pengalaman belajar yang diperoleh siswa dapat melalui proses perbuatan atau mengalami sendiri apa yang dipelajari, proses mengamati dan mendengarkan melalui media tertentu dan proses mendengarkan melalui bahasa. Berdasarkan penyataan tersebut, konsep dari teori cone of experience dapat memberikan gambaran bahwa apabila siswa diberikan materi bahan pelajaran berupa contoh-contoh secara konkret, maka siswa dapat memperoleh pengalaman yang bermakna. Jamil Suprihatiningrum (2013: 321) menyebutkan pula bahwa secara hierarki nilai pengalaman tingkatan tertinggi dari konsep media pembelajaran adalah melalui pengalaman konkret, sedangkan tingkatan terendah melalui pengalaman yang paling abstrak. Hal ini apabila dikaitkan dengan kapasitas pemikiran siswa SMP, maka dapat bersinergi sebab paradigma menalar siswa secara karakter mampu berpikir logis serta memori untuk menangkap informasi sudah terwujud.

\section{Kesimpulan dan Saran}

Setelah dilakukan pengembangan media pembelajaran multimedia heritage untuk siswa SMP, maka dapat disimpulkan sebagai berikut Pertama penggunaan media pembelajaran IPS di SMP Negeri 6 Kota Madiun dapat dikatakan belum maksimal. Guru masih terpaku pada buku teks dan belum memanfaatkan penggalian sumber belajar yang berada di lingkungan sekitar. Kedua, Hasil uji pada tahap skala diperluas menunjukkan perbedaan yang signifikan sebelum dan sesudang diterapkan multimedia heritage sebagai pengembangan media pembelajaran sebelumnya.Terbukti perolehan nilai pre-test dan post-test yang mengalami peningkatan. Perolehan hasil pada pengujian di SMP Negeri 6 Madiun dengan jumlah siswa 28 orang menunjukkan nilai pre-test 64,64 dan nilai post-test 93,21 dengan nilai signifikansinya 0,05 . Dari perolehan data sementara tersebut kemudian dilakukan perhitungan uji statistik dengan model Paired Samples T Test (Non-Independent). Apabila mengacu aturan hipotesis statistik nilai perhitungan tersebut adalah $<0,05$, dan itu artinya $H_{0}$ ditolak. Kesimpulan hipotesis tersebut adalah bahwa $H_{1}$ yang diterimasehingga ada peningkatan positif dan signifikan antara nilai siswa sebelum dan sesudah diberi multimedia heritage (media yang dikembangkan).

Diharapkan seorang guru dapat mensinergikan pembuatan bahan ajar dengan sintesa aplikasi teknologi yang berkembang. Tersedianya potensi lingkungan sekitar untuk pengayaan bahan ajar dengan kemasan yang menarik berbantu aplikasi yang ada seperti video menjadi alternatif media pembelajaran sehingga membantu kebermenarikan siswa tatkala belajar. Selain itu, sehubungan dengan materi dan aplikasi yang digunakan masih terbatas dan seiring perkembangan dinamika informasi pengetahuan maka dapat dilakukan penelitian pengembangan terutama media pembelajaran yang lebih lanjut sehingga peluang untuk menghasilkan media yang menarik serta relevan guna membantu guru dalam design pembelajaran yang bermakna.

\section{Daftar Pustaka}

Borg, Walter \& Gall, Meredith Damien. (2007). Educational Research.New York: Longman.

Deni Darmawan.(2012). Inovasi Pendidikan Pendekatan Praktik Teknologi Multimedia Dan Pembelajaran Online. Bandung: PT Remaja Rosdakarya.

Dian Din Astute Mulia. (2014). Pengembangan Mutual Differentiation Model Melalaui Dongeng Sebagai 


\section{gulawentah: Jurnal Studi Sosial}

Volume 1 Nomor 1 Juli 2016, hal 24-33

Avaliable online at http://e-journal.ikippgrimadiun.ac.id/index.php/gulawentah

Strategi Pembentukan Identitas Nasional Menghadapi Tantangan Multikulturalisme Sejak Usia Dini. Call For Papers Lolos Seleksi Kongres Pendidikan, Pengajaran dan Kebudayaan II. Yogyakarta: 21. (Abstr.).

Erna Febry Aries S. (2011). Asesmen dan Evaluasi. Malang: Aditya Media Publishing.

Hariyono.(2014). Merenung Ulang Pembelajaran Di Sekolah. Makalah disampaikan dalam Seminar Nasional Temu Alumni Program Studi Pendidikan Sejarah PPS FKIP-UNS, 26 Juni 2014.

Jamil Suprihatiningrum. (2013). Strategi Pembelajaran: Teori dan Aplikasi. Yogyakarta : Ar-Ruzz Media.

Mohd.Salleh Abu dan Zaid Zainal Abiding.(2012). Improving The Levels Of Geometric Thinking Of Secondary School Students Using Geometry Learning Video Based On Van Hiele Theory. International Journal Of Evaluation And Research In Education. Nomor 1, Volume 2 Maret 2013: PP. 16-22

Nur Ahyani. (2013). Kemampuan Berfikir Kritis Dalam Pembelajaran Sejarah. Makalah disajikan dalam Seminar Nasional Membangun Strategi Pembangunan Di Bidang Pendidikan Dan Kebudayaan, Universitas Sebelas Maret Surakarta, 7 Mei 2013.

Soebijantoro. (2012). Undang-Undang Benda Cagar Budaya Di Era Otonomi Daerah. Agastya: Jurnal Sejarah dan Pembelajarannya. No. 02 Tahun 2 Juni 2012: 103-111.

Sugiyono.(2013). Metode Penelitian Pendidikan: Pendekatan Kuantitatif, Kualitatif, dan $R \& D$. Bandung: Alfabeta.
Wina Sanjaya. (2008). Perencanaan dan Desain Sistem Pembelajaran. Jakarta: Kencana Prenada Media Group. 